\title{
Front Matter: Volume 9229
}

, "Front Matter: Volume 9229," Proc. SPIE 9229, Second International Conference on Remote Sensing and Geoinformation of the Environment (RSCy2014), 922901 (14 August 2014); doi: 10.1117/12.2076072

SPIE Event: Second International Conference on Remote Sensing and SPIE. Geoinformation of the Environment (RSCy2014), 2014, Paphos, Cyprus 


\title{
Second International Conference on Remote Sensing and Geoinformation of the Environment (RSCy2014)
}

\author{
Diofantos G. Hadjimitsis \\ Kyriacos Themistocleous \\ Silas Michaelides \\ Giorgos Papadavid \\ Editors
}

\section{7-10 April 2014 \\ Paphos, Cyprus}

Organized by

Cyprus Remote Sensing Society • Cyprus University of Technology

Co-organized by

ESA_European Space Agency • Cyprus Scientific and Technical Chamber (ETEK) • Department of Meteorology and Ministry of Defense (Cyprus) - Department of Electronic Communications of the Ministry of Communications and Works (Cyprus) • Agricultural Research Institute (Cyprus) • Hellas Sat • Neapolis University (Cyprus) • Frederick University (Cyprus) • European Cooperation in Science and Technology (COST)

Sponsored by

Intergraph (United States) • Geosystems Hellas (Greece) • European Cooperation in Science and Technology (COST) • Euro-agriwot • Li-Cor (United States) • Spectra Vista Corporation (United States) • Cyprus Associations of Civil Engineers • Pegeia Municipality (Cyprus) • Municipality of Pafos (Cyprus) • Agisoft (Russian Federation) • QuestUAV (United Kingdom) • Smart Events

Published by

SPIE

Volume 9229 
The papers included in this volume were part of the technical conference cited on the cover and title page. Papers were selected and subject to review by the editors and conference program committee. Some conference presentations may not be available for publication. The papers published in these proceedings reflect the work and thoughts of the authors and are published herein as submitted. The publisher is not responsible for the validity of the information or for any outcomes resulting from reliance thereon.

Please use the following format to cite material from this book:

Author(s), "Title of Paper," in Second International Conference on Remote Sensing and Geoinformation of the Environment (RSCy2014), edited by Diofantos G. Hadjimitsis, Kyriacos Themistocleous, Silas Michaelides, Giorgos Papadavid, Proceedings of SPIE Vol. 9229 (SPIE, Bellingham, WA, 2014) Article CID Number.

ISSN: 0277-786X

ISBN: 9781628412765

Published by

SPIE

P.O. Box 10, Bellingham, Washington 98227-0010 USA

Telephone +1 3606763290 (Pacific Time) · Fax +1 3606471445

SPIE.org

Copyright (C) 2014, Society of Photo-Optical Instrumentation Engineers.

Copying of material in this book for internal or personal use, or for the internal or personal use of specific clients, beyond the fair use provisions granted by the U.S. Copyright Law is authorized by SPIE subject to payment of copying fees. The Transactional Reporting Service base fee for this volume is $\$ 18.00$ per article (or portion thereof), which should be paid directly to the Copyright Clearance Center (CCC), 222 Rosewood Drive, Danvers, MA 01923. Payment may also be made electronically through CCC Online at copyright.com. Other copying for republication, resale, advertising or promotion, or any form of systematic or multiple reproduction of any material in this book is prohibited except with permission in writing from the publisher. The CCC fee code is 0277-786X/14/\$18.00.

Printed in the United States of America.

Publication of record for individual papers is online in the SPIE Digital Library.

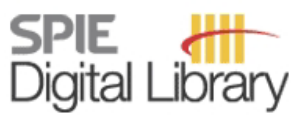

SPIEDigitalLibrary.org

Paper Numbering: Proceedings of SPIE follow an e-First publication model, with papers published first online and then in print and on CD-ROM. Papers are published as they are submitted and meet publication criteria. A unique, consistent, permanent citation identifier (CID) number is assigned to each article at the time of the first publication. Utilization of CIDs allows articles to be fully citable as soon as they are published online, and connects the same identifier to all online, print, and electronic versions of the publication. SPIE uses a six-digit CID article numbering system in which:

- The first four digits correspond to the SPIE volume number.

- The last two digits indicate publication order within the volume using a Base 36 numbering

system employing both numerals and letters. These two-number sets start with 00, 01, 02, 03, 04, $05,06,07,08,09,0 A, 0 B \ldots$. 0Z, followed by 10-1Z, 20-2Z, etc.

The CID Number appears on each page of the manuscript. The complete citation is used on the first page, and an abbreviated version on subsequent pages. Numbers in the index correspond to the last two digits of the six-digit CID Number. 


\title{
Contents
}

\author{
xi Conference Committee \\ $\mathrm{xv}$ Introduction
}

\section{LIDAR}

922904 High spatial resolution $\mathrm{NO}_{2}$ tropospheric slant columns retrieved from OMI spatial-zoom spectra using an earthshine reference [9229-14]

J. S. Anand, R. J. Leigh, P. S. Monks, Univ. of Leicester (United Kingdom)

922905 Investigation on the contribution of LiDAR data in 3D cadastre [9229-13]

O. Giannaka, E. Dimopoulou, A. Georgopoulos, National Technical Univ. of Athens (Greece)

922906 Study of cloud properties using airborne and satellite measurements [9229-16] A. Boscornea, Univ. of Bucharest (Romania) and INCAS - National Institute for Aerospace Research Elie Carafoli (Romania); S. Stefan, Univ. of Bucharest (Romania); S. Vajaiac, Univ. of Bucharest (Romania) and INCAS - National Institute for Aerospace Research Elie Carafoli (Romania)

922907 European meteorological data: contribution to research, development, and policy support [9229-22]

I. Biavetti, S. Karetsos, A. Ceglar, A. Toreti, P. Panagos, European Commission Joint Research Ctr. (Italy)

GIS

922908 Integrating GIS and genetic algorithms for automating land partitioning [9229-1]

D. Demetriou, Univ. of Leeds (United Kingdom); L. See, International Institute for Applied Systems Analysis (Austria) and Univ. College London (United Kingdom); J. Stillwell, Univ. of Leeds (United Kingdom)

922909 Importance of the spatial data and the sensor web in the ubiquitous computing area [9229-67]

N. Akçit, E. Tomur, M. O. Karslıoğlu, Middle East Technical Univ. (Turkey)

9229 OA Digital surveying and mapping of forest road network for development of a GIS tool for the effective protection and management of natural ecosystems [9229-81]

V. C. Drosos, S.-A. G. Liampas, Democritus Univ. of Thrace (Greece); A.-K. G. Doukas, Aristotle Univ. of Thessaloniki (Greece) 
9229 OC Subsurface geological modeling using GIS and remote sensing data: a case study from Platanos landslide, Western Greece [9229-41]

K. Kavoura, M. Kordouli, K. Nikolakopoulos, Univ. of Patras (Greece); P. Elias, O. Sykioti, IAASARS, National Observatory of Athens (Greece); V. Tsagaris, Univ. of Patras (Greece); G. Drakatos, GEIN, National Observatory of Athens (Greece); Th. Rondoyanni, G. Tsiambaos, National Technical Univ. of Athens (Greece); N. Sabatakakis, V. Anastasopoulos, Univ. of Patras (Greece)

9229 OD Integrated GIS and remote sensing analysis for landslide susceptibility mapping in Crete [9229-26]

M. Kouli, P. Soupios, F. Vallianatos, Technological Educational Institute of Crete (Greece)

9229 OE Cost effective accurate orthoimaging of inaccessible areas [9229-29]

P. Fragkos, C. Ioannidis, National Technical Univ. of Athens (Greece)

9229 OF Predicting soil organic carbon content in Cyprus using remote sensing and Earth observation data [9229-46]

C. Ballabio, P. Panagos, L. Montanarella, European Commission Joint Research Ctr. (Italy)

9229 OG Land subsidence in southwest Cyprus revealed from C-band radar interferometry [9229-97] P. Michalis, A. Giourou, B. Charalampopoulou, Geosystems Hellas (Greece); Z. Li, Newcastle Univ. (United Kingdom); Y. Li, Newcastle Univ. (United Kingdom) and China Earthquake Administration (China)

\section{HAZARDS}

$9229 \mathrm{OH}$ Data Acquisition (DAQ) system dedicated for remote sensing applications on Unmanned Aerial Vehicles (UAV) [9229-19]

C. Keleshis, S. Ioannou, M. Vrekoussis, The Cyprus Institute (Cyprus); Z. Levin, The Cyprus Institute (Cyprus) and Tel Aviv Univ. (Israel); M. A. Lange, The Cyprus Institute (Cyprus)

9229 ol Advances in soil erosion modelling through remote sensing data availability at European scale [9229-44]

P. Panagos, European Commission Joint Research Ctr. (Italy); C. Karydas, Aristotle Univ. of Thessaloniki (Greece); P. Borrelli, C. Ballabio, European Commission Joint Research Ctr. (Italy); K. Meusburger, Univ. Basel (Switzerland)

\section{REMOTE SENSING VEGETATION INDICES}

9229 0J Investigation of spatial relationships between crop coefficients and specific ground based vegetation indices for Karla watershed, Greece [9229-9]

M. Spiliotopoulos, A. Loukas, N. Mylopoulos, Univ. of Thessaly (Greece) and Institute for Research and Technology of Thessaly (Greece); L. Toulios, National Agricultural Research Foundation (Greece); G. Stancalie, National Meteorological Administration (Romania) 
9229 OK Potential of using satellite based vegetation indices and biophysical variables for the assessment of the water footprint of crops [9229-45]

Gh. Stancalie, A. T. Nertan, National Meteorological Administration (Romania); L. Toulios, National Agricultural Research Foundation (Greece); M. Spiliotopoulos, Univ. of Thessaly (Greece)

$9229 \mathrm{OL} \quad$ Establishing a method for estimating crop water requirements using the SEBAL method in Cyprus [9229-64] G. Papadavid, Agricultural Research Institute (Cyprus); L. Toulios, National Agricultural Research Foundation (Greece); D. Hadjimitsis, Cyprus Univ. of Technology (Cyprus); G. Kountios, Agricultural Research Institute (Cyprus)

9229 OM Satellite-derived land use changes along the Xin'an River watershed for supporting water quality investigation for potential fishing grounds in Qiandao Lake, China [9229-32]

A. Agapiou, D. D. Alexakis, Cyprus Univ. of Technology (Cyprus); A. Sarris, Foundation for Research and Technology-Hellas (Greece); K. Themistocleous, C. Papoutsa,

D. G. Hadjimitsis, Cyprus Univ. of Technology (Cyprus)

\section{REMOTE SENSING IN URBAN AREAS}

922900 Comparative analysis of property taxation policies within Greece and Cyprus evaluating the use of GIS, CAMA, and remote sensing techniques [9229-98] T. Dimopoulos, Cyprus Univ. of Technology (Cyprus); T. Labropoulos, National Technical Univ. of Athens (Greece); D. G. Hadjimitsis, Cyprus Univ. of Technology (Cyprus)

9229 OP Integration of different geospatial data in urban areas: a case of study [9229-54] F. Franci, A. Lambertini, G. Bitelli, Univ. degli Studi di Bologna (Italy)

$92290 Q$ Effects of tourism and globalization on land cover and the influence on the quality of life of Paphos area in Cyprus [9229-91]

C. Italos, E. Akylas, D. G. Hadjimitsis, Cyprus Univ. of Technology (Cyprus)

9229 OR Photogrammetry and remote sensing on urban areas [9229-11]

M. A. Lazaridou, Aristotle Univ. of Thessaloniki (Greece)

9229 OS The use of UAV platforms for remote sensing applications: case studies in Cyprus [9229-75] K. Themistocleous, Cyprus Univ. of Technology (Cyprus)

\section{LAND COVER/USE}

9229 OT Geoinformation technologies in sustainable spatial planning: a Geodesign approach to local land-use planning [9229-17]

M. Campagna, A. Matta, Univ. degli Studi di Cagliari (Italy)

9229 OU Evaluation of sustainability indices and indicators in the Paphos district area in Cyprus [9229-93]

C. Italos, E. Akylas, Cyprus Univ. of Technology (Cyprus); D. Karidis, National Technical Univ. of Athens (Greece); D. G. Hadjimitsis, Cyprus Univ. of Technology (Cyprus) 
9229 OV Use of Landsat imagery to detect land cover changes for monitoring soil sealing: case study: Bologna province (Italy) [9229-50]

R. Casciere, F. Franci, G. Bitelli, Univ. degli Studi di Bologna (Italy)

\section{ENVIRONMENTAL}

9229 OW Integration of geoinformatics and wireless sensors for smart agriculture in tea [9229-42] N. Gupta, P. P. Gupta, P. Pramanik, A. Saikia, Tea Research Association (India); L. Sengupta, Ctr. for Development of Advanced Computing (India); R. M. Bhagat, Tea Research Association (India); N. Bhattacharya, Ctr. for Development of Advanced Computing (India)

9229 OX Meteorological radar services: a brief discussion and a solution in practice [9229-4] K. A. Nicolaides, Cyprus Dept. of Meteorology (Cyprus)

9229 OY Effect of environmental deterioration on buildings: a condition assessment case study [9229-88]

G. Christou, E. A. Tantele, R. A. Votsis, Cyprus Univ. of Technology (Cyprus)

$92290 Z$ An image based method for crop yield prediction using remotely sensed and crop canopy data: the case of Paphos district, western Cyprus [9229-65] G. Papadavid, Agricultural Research Institute (Cyprus); D. Hadjimitsis, Cyprus Univ. of Technology (Cyprus)

922910 The further environmental development of Polyphyto Hydroelectric Project reservoir in Kozani prefecture and its contribution to the life quality improvement [9229-57]

C. Saounatsou, Hellenic Open Univ. (Greece); J. Georgi, Neapolis Univ. of Pafos (Cyprus)

\section{WATER SCIENCES}

922911 Monitoring water quality parameters for Case II waters in Cyprus using satellite data [9229-90] C. Papoutsa, Cyprus Univ. of Technology (Cyprus); A. Retalis, National Observatory of Athens (Greece); L. Toulios, National Agricultural Research Foundation (Greece); D. G. Hadjimitsis, Cyprus Univ. of Technology (Cyprus)

922912 Identification of the key variables that can be estimated using remote sensing data and needed for Water Footprint (WF) assessment [9229-10]

M. Romaguera, Univ. of Twente (Netherlands); L. Toulios, National Agricultural Research Foundation (Greece); G. Stancalie, A. Nertan, National Meteorological Administration (Romania); M. Spiliotopoulos, Univ. of Thessaly (Greece); P. Struzik, Institute of Meteorology and Water Management (Poland); E. J. Calleja, Malta College for Science and Technology (Malta); G. Papadavid, Agricultural Research Institute (Cyprus)

922913 Evapotranspiration as a component of water footprint: use of conventional and satellite data for better estimation of spatial and temporal pattern [9229-8]

P. Struzik, M. Kepinska-Kasprzak, Institute of Meteorology and Water Management (Poland) 
922914 What's next in remote sensing archaeology? Use of field spectroscopy to design a new space sensor (Invited Paper) [9229-102]

D. G. Hadjimitsis, Cyprus Univ. of Technology (Cyprus)

922916 4D reconstruction of the past: the image retrieval and 3D model construction pipeline [9229-5]

A. Hadjiprocopis, M. Ioannides, Cyprus Univ. of Technology (Cyprus); K. Wenzel,

M. Rothermel, Univ. Stuttgart (Germany); P. S. Johnsons, 7Reasons GmbH (Austria);

D. Fritsch, Univ. Stuttgart (Germany); A. Doulamis, E. Protopapadakis, G. Kyriakaki,

K. Makantasis, Technical Univ. of Crete (Greece); G. Weinlinger, M. Klein, 7Reasons GmbH

(Austria); D. Fellner, A. Stork, P. Santos, Fraunhofer Institute for Computer Graphics Research

922917 3D laser scanning and modelling of the Dhow heritage for the Qatar National Museum [9229-43]

A. Wetherelt, J. P. Cooper, Univ. of Exeter (United Kingdom); C. Zazzaro, Univ. of Naples (Italy)

\section{SATELLITE AND WATER RESOURCES}

922918 Delineating hydrological response units in a mountainous catchment and its evaluation on water mass balance and model performance [9229-63]

E. Savvidou, Cyprus Univ. of Technology (Cyprus); O. Tzoraki, Univ. of the Aegean (Greece);

D. Skarlatos, Cyprus Univ. of Technology (Cyprus)

922919 New toolbox in ArcGIS for the reconstruction of missing satellite data using DINEOF algorithm: a case study of reconstruction of Chlorophyll-a gaps over the Mediterranean Sea [9229-87]

A. Nikolaidis, Cyprus Univ. of Technology (Cyprus) and Univ. of Cyprus (Cyprus); S. Stylianou, G. Georgiou, Univ. of Cyprus (Cyprus); D. Hadjimitsis, E. Akylas, Cyprus Univ. of Technology (Cyprus)

9229 1 A Spiral eddies in the Aegean Sea derived by satellite radar data [9229-25]

A. Tavri, K. Topouzelis, E. Tragou, Univ. of the Aegean (Greece)

FORESTS

9229 1B A decision support tool for visibility analysis: the probabilistic algorithm GAVOS [9229-24]

G. A. Achilleos, Cyprus Univ. of Technology (Cyprus)

9229 1C Forest construction infrastructures for the prevision, suppression, and protection before and after forest fires [9229-83]

V. C. Drosos, Democritus Univ. of Thrace (Greece); V. J. Giannoulas, Aristotle Univ. of Thessaloniki (Greece); C. Daoutis, Democritus Univ. of Thrace (Greece) 
9229 ID (Semi) automatic extraction from airborne laser scan data of roads and paths in forested areas [9229-89]

W. F. Vletter, Univ. of Vienna (Austria)

9229 1E Determining aboveground biomass of the forest successional chronosequence in a testsite of Brazilian Amazon through X- and L-band data analysis [9229-6]

J. R. Santos, C. V. de Jesus Silva, L. S. Galvão, National Institute for Space Research (Brazil);

R. Treuhaft, Jet Propulsion Lab. (United States); J. C. Mura, National Institute for Space Research (Brazil); S. Madsen, Jet Propulsion Lab. (United States); F. G. Gonçalves, Woods Hole Research Ctr. (United States); M. M. Keller, U.S. Forest Service (United States) and Univ. of New Hampshire (United States)

$9229 \mathrm{IF} \quad$ Cadastre (forest maps) and spatial land uses planning, strategic tool for sustainable development [9229-82]

V. C. Drosos, Democritus Univ. of Thrace (Greece)

9229 1G Protection against fire in the mountainous forests of Greece case study: forest complex of W. Nestos [9229-84]

V. C. Drosos, Democritus Univ. of Thrace (Greece); V. J. Giannoulas, A. Stergiadou,

E. Karagiannis, A.-K. G. Doukas, Aristotle Univ. of Thessaloniki (Greece)

$92291 \mathrm{H} \quad$ Leading time domain seismic precursors [9229-33]

A. C. Boucouvalas, M. Gkasios, A. Keskebes, N. T. Tselikas, Univ. of Peloponnese (Greece)

$922911 \quad$ Field dynamic testing on a Cyprus concrete highway bridge using Wireless Sensor Network (WSN) [9229-85]

R. A. Votsis, N. Kyriakides, E. A. Tantele, C. Z. Chrysostomou, T. Onoufriou, Cyprus Univ. of Technology (Cyprus)

9229 i Hazard analysis of active tectonics through geomorphometric parameters to cultural heritage conservation: the case of Paphos in Cyprus [9229-18]

A. V. Argyriou, Foundation for Research and Technology-Hellas (Greece) and Univ. of Portsmouth (United Kingdom); A. Sarris, Foundation for Research and Technology-Hellas (Greece); D. Alexakis, A. Agapiou, K. Themistocleous, Cyprus Univ. of Technology (Cyprus); V. Lysandrou, Kykkos Museum (Cyprus); D. Hadjimitsis, Cyprus Univ. of Technology (Cyprus)

POSTER SESSION: AGRICULTURE

$92291 \mathrm{~K}$ Determination of phenological parameters from MODIS derived NDVI data using hidden Markov models [9229-34]

M. A. García, H. Moutahir, S. Bautista, F. Rodríguez, Univ. de Alicante (Spain) 
9229 1L Geodiametris: an integrated geoinformatic approach for monitoring land pollution from the disposal of olive oil mill wastes [9229-39]

D. D. Alexakis, A. Sarris, N. Papadopoulos, Foundation for Research and Technology-Hellas (Greece); P. Soupios, Technological Educational Institute of Crete (Greece); M. Doula, V. Cavvadias, National Agricultural Research Foundation (Greece)

9229 1M Rockfall detection along road networks using close range photogrammetry [9229-66] P. Partsinevelos, S. Mertikas, Z. Agioutantis, Technical Univ. of Crete (Greece); V. Tsioukas, Aristotle Univ. of Thessaloniki (Greece); A. Tripolitsiotis, P. Zervos, Technical Univ. of Crete (Greece)

9229 iN Forecasting precipitation and temperatures at the island of Cyprus to enhance wetland management [9229-27]

G. Spanou, K. K. loannou, Eastern Macedonia and Thrace Institute of Technology (Greece); V. lakovoglou, DEMETER-FRI (Greece); G. N. Zaimes, Eastern Macedonia and Thrace Institute of Technology (Greece)

922910 Damage assessment using advanced non-intrusive inspection methods: integration of space, UAV, GPR, and field spectroscopy [9229-70]

K. Themistocleous, K. Neocleous, Cyprus Univ. of Technology (Cyprus); K. Pilakoutas, The Univ. of Sheffield (United Kingdom); D. G. Hadjimitsis, Cyprus Univ. of Technology (Cyprus)

POSTER SESSION: GEOLOGY

9229 1P Monitoring of olive oil mills' wastes using electrical resistivity tomography techniques [9229-28]

K. Simyrdanis, N. Papadopoulos, Foundation for Research and Technology-Hellas (Greece); S. Kirkou, Foundation for Research and Technology-Hellas (Greece) and Aristotle Univ. of Thessaloniki (Greece); A. Sarris, Foundation for Research and Technology-Hellas (Greece); P. Tsourlos, Aristotle Univ. of Thessaloniki (Greece)

\section{POSTER SESSION: GIS}

9229 1Q Development of a geographical information system for risk mapping of reinforced concrete buildings subjected to atmospheric corrosion in Cyprus using optical remote sensing data [9229-23]

K. Neocleous, A. Agapiou, A. Christofe, K. Themistocleous, Z. Achillides, M. Panayiotou, D. G. Hadjimitsis, Cyprus Univ. of Technology (Cyprus)

\section{POSTER SESSION: REMOTE SENSING}

9229 IT Sustainable transport planning using GIS and remote sensing: an integrated approach [9229-103]

M. D. Giorgoudis, D. G. Hadjimitsis, Cyprus Univ. of Technology (Cyprus); Y. Shiftan,

Technion-Israel Institute of Technology (Israel) 
$92291 \mathrm{U}$ Remote sensing application for identifying wetland sites on Cyprus: problems and prospects [9229-12]

V. Markogianni, Hellenic Ctr. for Marine Research (Greece); E. Tzirkalli, Univ. of Ioannina (Greece) and Frederick Univ. (Cyprus); S. Gücel, Near East Univ. (Cyprus); E. Dimitriou, S. Zogaris, Hellenic Ctr. for Marine Research (Greece)

9229 IV Use of remote sensing and UAV for the management of degraded ecosystems: the case study of overgrazing in Randi Forest, Cyprus [9229-76]

K. Themistocleous, Cyprus Univ. of Technology (Cyprus); G. Papadavid, Agricultural Research Institute (Cyprus); M. Christoforou, A. Agapiou, K. Andreou, D. Tsaltas,

D. G. Hadjimitsis, Cyprus Univ. of Technology (Cyprus)

\section{POSTER SESSION: WATER SCIENCE}

9229 IW User interface considerations for telerobotics: the case of an agricultural robot sprayer [9229-62]

G. Adamides, Open Univ. of Cyprus (Cyprus); C. Katsanos, Hellenic Open Univ. (Greece);

G. Christou, European Univ. of Cyprus (Cyprus); M. Xenos, Hellenic Open Univ. (Greece);

G. Papadavid, Agricultural Research Institute (Cyprus); T. Hadzilacos, Open Univ. of Cyprus (Cyprus)

$92291 \mathrm{X}$ The use of GIS for supporting the experimental representation of the selected supply network in the Pafos municipality: the HydroGIS Lab [9229-78]

K. Themistocleous, Pl. Evlogimenos, A. Agapiou, M. Theodorou, C. Demetriades,

D. G. Hadjimitsis, Cyprus Univ. of Technology (Cyprus)

9229 IY Ship extraction and categorization from ASTER VNIR imagery [9229-68]

P. Partsinevelos, Technical Univ. of Crete (Greece); G. Miliaresis, Open Univ. of Cyprus (Cyprus)

Author Index 


\section{Conference Committee}

\section{Conference Chairs}

Diofantos G. Hadjimitsis, Cyprus University of Technology (Cyprus)

Kyriacos Themistocleous, Cyprus Remote Sensing Society (Cyprus)

Silas Michaelides, Department of Meteorology, Ministry of

Agriculture, Natural Resources and Environment (Cyprus)

Giorgos Papadavid, Agricultural Research Institute (Cyprus)

International Scientific Committee

Ammatzia Peled, Department of Geography and Environmental Studies (Israel)

Chris Clayton, University of Southampton (United Kingdom)

Massimo Menenti, Delft University of Technology (Netherlands)

Marinos Kavouras, National Technical University of Athens (Greece)

Gunter Menz, University of Bonn (Germany)

Dimitrios Argialas, National Technical University of Athens (Greece)

Yerach Doytsher, Technion - Israel Institute of Technology (Israel)

Alexandros Papayannis, National Technical University of Athens (Greece)

Rosa Lasaponara, National Research Council, Institute for Environmental Analysis (Italy)

Andreas Georgopoulos, National Technical University of Athens (Greece)

Athanasios Loukas, University of Thessaly (Greece)

Vassilia Karathanassi, National Technical University of Athens (Greece)

Marco Gianinetto, Politecnico di Milano (Italy)

Julia Georgi, Neapolis University (Cyprus)

Alexandros Savvaidis, Institute of Engineering Seismology and Earthquake Engineering (Greece)

loannis Gitas, Aristotle University of Thessaloniki (Greece)

Kevin Tansey, University of Leicester (United Kingdom)

Nicola Masini, Institute for Archaeological and Architectural Heritage (Italy)

Athanassios Ganas, National Observatory of Athens (Greece)

Apostolos Sarris, Foundation for Research and Technology - Hellas (Greece)

Adrianos Retalis-National Observatory of Athens (Greece)

Nektarios Chrysoulakis, Foundation for Research and

Technology - Hellas (Greece) 
Albert Ansmann, Leibniz Institute for Tropospheric Research

(Germany)

Charalampos loannidis, National Technical University of Athens

(Greece)

Leonidas Toulios, Hellenic Agricultural Organisation DEMETER

(NAGREF) (Greece)

Chryssy Potsiou National Technical University of Athens (Greece)

Vasileios Drosos, Democritus University of Thrace (Greece)

Denitsa Borisova, Bulgarian Academy of Sciences (Bulgaria)

Konstantinos Nikolakopoulos, University of Patras (Greece)

Dimitrios Alexakis, Foundation for Research and Technology - Hellas

(Greece)

Local Scientific Committee

Diofantos G. Hadjimitsis, Cyprus University of Technology (Cyprus)

Kyriacos Themistocleous, Cyprus Remote Sensing Society (Cyprus)

Giorgos Papadavid, Agricultural Research Institute (Cyprus)

Silas Michaelides, Department of Meteorology, Ministry of

Agriculture, Natural Resources and Environment (Cyprus)

Skevi Perdikou, Frederick University (Cyprus)

Athos Agapiou, Cyprus University of Technology (Cyprus)

Christodoulos Protopapas, Hellas Sat (Cyprus)

George Komodromos, Department of Electronic Communications of the Ministry of Communications and Works (Cyprus)

Tasos Elia, Department of Electronic Communications of the Ministry of Communications and Works (Cyprus)

Christiana Papoutsa, Cyprus University of Technology (Cyprus)

Marios Tzouvaras, Cyprus University of Technology (Cyprus)

Argyro Nisantzi, Cyprus University of Technology (Cyprus)

Rodanthi Mammouri, Cyprus University of Technology (Cyprus)

Kyriacos Neocleous, Cyprus University of Technology (Cyprus)

Chrysostomos Italos, Cyprus University of Technology (Cyprus)

Andreas Christofi, Cyprus University of Technology (Cyprus)

Branca Cuca, Cyprus University of Technology (Cyprus)

Kostas Papageorgiou, Department of Forests (Cyprus) and Cyprus

University of Technology (Cyprus)

Demetrios Alexakis, Cyprus University of Technology (Cyprus)

Andreas Papachristodoulou, Cyprus University of Technology (Cyprus)

Michalakis Christoforou, Cyprus University of Technology (Cyprus) 
Session Chairs

1 LIDAR

A. Ansmann, Leibniz Institute for Tropospheric Research (Germany)

2 GIS

K. Tansey, University of Leicester (United States)

3 Geology

I. Woodhouse, University of Edinburgh (United Kingdom)

$4 \quad$ Remote Sensing Vegetation Indices

S. Bautista, Universidad de Alicante (Spain)

5 Hazards

G. Papadavid, Agricultural Research Institute (Cyprus)

$6 \quad$ Remote Sensing in Urban Areas

D. Demetriou, University of Leeds (United Kingdom)

$7 \quad$ Land Cover/Use

M. Campagna, Università di Cagliari (Italy)

8 Environmental

F. Rodriguez, Universidad de Alicante (Spain)

9 Cultural Heritage

A. Wetherelt, University of Exeter (United Kingdom)

10 Water Sciences

A. Loukas, University of Thessaly (Greece)

11 Satellite and Water Resources

P. Struzik, Institute of Meteorology and Water Management (Poland)

12 Forests

W. Vletter, Vienna Institute for Archaeological Science (Austria)

13 Seismic

A. Boucouvalas, University of Peloponnese (Greece) 
Proc. of SPIE Vol. 9229 922901-14

Downloaded From: https://www.spiedigitallibrary.org/conference-proceedings-of-spie on 26 Apr 2023 Terms of Use: https://www.spiedigitallibrary.org/terms-of-use 


\section{Introduction}

Following the success of the First International Conference on Remote Sensing and Geoinformation of Environment, RSCy2013 in Paphos, Cyprus that took place 8-10 April 2013, the Cyprus Remote Sensing Society and the Cyprus University of Technology organized the Second International Conference on Remote Sensing and Geoinformation of Environment, RSCy2014. The organizing committee, scientific committee, and editors would like to thank the authors and participants who attended the Second International Conference on Remote Sensing and Geoinformation of Environment in Paphos, Cyprus, 7-10 April 2014.

The conference focused on emerging issues in remote sensing and geoinformation of environment. It was attended by professionals from over 30 countries. The keynote speakers and diverse technical program encouraged the exchange of ideas and provided the foundation for future collaboration and innovation. The conference was enhanced by the inclusion of two workshops on ERDAS and LiDAR processing. The RSCy2014 Conference was organized by the Cyprus Remote Sensing Society, Cyprus University of Technology, ESA (European Space Agency), ETEK (Cyprus Scientific and Technical Chamber), Ministry of Defense, Department of Meteorology of the Ministry of Agriculture, Natural Resources and Environment, Department of Electronic Communications of the Ministry of Communications and Works, Frederick University, Neapolis University and COST (European Cooperation in Science and Technology).

The following papers, reviewed for presentation and accepted for publication by the scientific committee, represent continued advancements in the field of remote sensing and geo-information. The program, which included both oral and poster presentations, was organized around the following major themes: Agriculture, Atmospheric, Archaeology-Cultural Heritage, Environmental Applications, Forests-Fires, Geology, GIS, Land Cover and Land Use, LIDAR, Remote Sensing, Seismic, and Water Sciences. The abstracts and subsequent papers make important contributions to the open scientific literature on remote sensing and geo-information. We thank the authors for sharing their knowledge and enthusiasm.

We would like to especially thank the Conference chairs who provided invaluable assistance during the Conference. Thanks are also due to the staff at SPIE for following the proceedings through the publication process.

Diofantos G. Hadjimitsis Kyriacos Themistocleous Silas Michaelides Giorgos Papadavid 
Proc. of SPIE Vol. 9229 922901-16

Downloaded From: https://www.spiedigitallibrary.org/conference-proceedings-of-spie on 26 Apr 2023 Terms of Use: https://www.spiedigitallibrary.org/terms-of-use 